\title{
Opportunities and challenges for implementing managed aquifer recharge models in drought-prone Barind tract, Bangladesh
}

\author{
Md. Iquebal Hossain ${ }^{1,2} \cdot$ Md. Niamul Bari² $\cdot$ Md. Shafi Uddin Miah ${ }^{2}$
}

Received: 21 December 2019 / Accepted: 26 October 2021 / Published online: 5 November 2021

(c) The Author(s) 2021

\begin{abstract}
This study focuses on the Barind tract, a drought prone area situated in the north-west region of Bangladesh where inadequate rainfall and limited surface water have created high dependence on groundwater for irrigation and other purposes, leading to significant declines in groundwater level. Managed aquifer recharge (MAR) offers a potential solution to restore groundwater levels. This study sets out to identify the opportunities and challenges for implementing MAR in the Barind tract. To accomplish this aim, different data sets including bore log lithology, rainfall, groundwater levels, information about re-excavated ponds, dighis, kharies, beels, check dams, rubber dams, dug wells and other necessary information were collected from the Barind Multipurpose Development Authority (BMDA) and other sources and analyzed. Major opportunities for MAR are identified for about $2000 \mathrm{~km}$ of re-excavated kharies (canals) containing about 750 check dams, more than 3000 re-excavated ponds, a number of beels (comparatively large marshes) and other water bodies which are used to conserve runoff storm water for supplementary irrigation. The conserved water can be used for groundwater recharge and subsequently abstracted for irrigation. Furthermore, roof-top rain water from buildings can also be used for groundwater recharge purposes. In contrast, the major challenges include the high turbidity of storm water runoff leading to clogging of MAR structures, inadequacy of conventional direct surface methods of recharge due to the presence of a $15 \mathrm{~m}$ or more thick upper clay layer with limited percolation capacity, and lack of practical knowledge on MAR. Therefore, overcoming the challenges for MAR application is a prerequisite to maximize the opportunities from MAR that can support the sustainable use of groundwater resources.
\end{abstract}

Keywords Managed aquifer recharge $\cdot$ Recharge well $\cdot$ Groundwater $\cdot$ Sustainable $\cdot$ Clogging $\cdot$ Barind tract $\cdot$ Bangladesh

\section{Introduction}

Water is the most valuable gift of nature. However, its distribution on the Earth's surface is extremely uneven. It is estimated that the earth contains about 1.386 billion cubic kilometers of water of which about $97 \%$ is saline water lies in the form of seas and oceans. Only $3 \%$ of the water available on earth is fresh water. Almost $66.7 \%$ of the fresh water is in the form of ice caps and glaciers and about $30.1 \%$ exists below the surface as groundwater. The surface water which is directly available is only $0.3 \%$ in the form of lakes, swamps and running water as rivers and the rest $0.9 \%$ are existing as

Md. Iquebal Hossain

iquebal_hossain@yahoo.com

1 Barind Multipurpose Development Authority, Rajshahi, Bangladesh

2 Department of Civil Engineering, Rajshahi University of Engineering \& Technology, Rajshahi, Bangladesh water vapor and soil water (Baker et al. 2016; Genda 2016; Balasubramanian 2015). The World Economic Forum mentioned in 2019 that the scarcity of fresh water resources to meet water demand that affects every continent is one of the largest global risks in terms of potential impact over the next decade (WEF 2019). One-third of the global population (2 billion people) lives under conditions of severe water scarcity at least 1 month of the year. Half a billion people in the world face severe water scarcity all year round. Half of the world's largest cities experience water scarcity (Mekonnen et al. 2016).

Barind tract is a physiographic unit located in the northwestern part of Bangladesh having gross area of 7,727 sq $\mathrm{km}$ (Rasheed 2008). Geographically this unit lies between $24^{\circ} 20^{\prime} \mathrm{N}$ and $25^{\circ} 35^{\prime} \mathrm{N}$ latitudes and $88^{\circ} 20^{\prime} \mathrm{E}$ and $89^{\circ} 30^{\prime} \mathrm{E}$ longitudes. Barind tract made up of Pleistocene Alluvium is also known as Older Alluvium and floored by reddish, brown, sticky Pleistocene sediment, Madhupur Clay (Ahmed 2006). The hard red soil, typical dry climate with 
comparatively high temperature varies from 8 to $44{ }^{\circ} \mathrm{C}$ (Ahmeduzzaman et al. 2012), and less rainfall of these areas is very significant in comparison to that of the other parts of the country (BMDA 2018). Averages annual rainfall ranges from minimum $1250 \mathrm{~mm}$ to maximum $2000 \mathrm{~mm}$ and almost $80 \%$ of the rainfall occurs during June to October (IWM 2012). Geomorphologically the area is subdivided into three geological units as: (1) Barind clay residuum-overlies and developed on Pleistocene alluvium; (2) Holocene Ganges flood-plain alluvium; (3) Active channel deposits of the Ganges and major distributaries (modern alluvium). It is the most drought prone water scarce area in Bangladesh. Drought is a natural hazard found in this area frequently. Groundwater drought, a kind of hydrological drought and agricultural drought related to meteorological phenomena occurs in the area. It has experienced moderate to extreme agricultural droughts with hydrological droughts in the years of 1972, 1975, 1979, 1982, 1986, 1989, 1992, 1994, 2003, 2005, 2009 and 2010 (Rahman et al. 2017). The surface water sources are very limited and there is no river flowing through the Barind tract. Due to scarcity of surface water and less rainfall, cultivation as well as irrigation in this area have become dependent on groundwater. Barind Multipurpose Development Authority (BMDA) mostly provides the irrigation from groundwater with deep tube well (DTW). More than 15,000 deep tube wells have been installed in the north-west region (Barind tract) by BMDA and private initiatives. The DTWs and shallow tube wells (STWs) are always engaged to withdraw groundwater for irrigation excessively, and due to the over exploitation groundwater table (GWT) is going down day by day (Jahan et al. 2010; Rahman et al. 2016a, b, 2017). However, storm water is the only source of GW recharge as the area is flood free (IWM 2012; Rahman and Mahbub 2012). But the storm water cannot percolate easily due to top clay layer more than $15 \mathrm{~m}$ thick and low infiltration capacity $(2-3 \mathrm{~mm}$ /day) (Jahan 2010) which caused reduction in the natural recharge of groundwater (Jahan et al. 2007, 2015).

Due to excessive withdrawal of groundwater for irrigation, less rainfall, hot temperature, low natural recharge and low flow in the major rivers in the dry season, ground water level has been falling all over the region (Imon and Ahmed 2013). Rahman and Mahbub (2012) also observed the depletion of groundwater level at the rate of $0.42 \mathrm{~m} /$ year in wet season and $0.22 \mathrm{~m} /$ year in dry season in the Tanore Upazila of the study area. The higher depletion rate in wet season compared to dry season is might be due to very close location from the River Shiba and wetland Beelkumari which give this area a higher recharging rate (Rahman and Mahbub 2012). The study area lies at Godagari, Tanore, Nachole and Niamatpur upazila under Rajshahi, Chapai Nawabgonj and Naogaon districts of Barind tract, respectively, which is shown in Fig. 1. The hydraulic conductivity of the aquifer varies from 18 to $29 \mathrm{~m} /$ day for Godagari, 39-56 m/day for Tanore, $12-35 \mathrm{~m} /$ day for Niamatpur and $12-17 \mathrm{~m} /$ day for Nachole Upazila (IWM 2012). IWM calculated potential recharge using mathematical modeling tool and found 521, 357, 451 and $496 \mathrm{~mm}$ for Godagari, Tanore, Niamatpur and Nachole Upazila, respectively (IWM 2012).

Groundwater plays a vital role in sustaining economy, environment and livelihood (Rahman et al. 2019). Continuous depletion of GWT may pose serious impact on the environment. But due to continuous lowering of groundwater level in the Barind tract, shallow tube wells and hand pumps are not functioning. To overcome this problem high-head force mode pump has been installed for withdrawing water from deep aquifer which increased the cost of drinking water as well as irrigation. Not only that many people are to collect drinking water from the distant place and some of them even use contaminated pond water for domestic purpose and they have to suffer from waterborne diseases. So the continuous depletion of groundwater level results resource unsustainable economically, socially and environmentally at Barind tract (Mojid et al. 2019; Jahan et al. 2010; Rahman et al. 2016a, b, 2017).

Therefore, to reverse the declining trend of GWT and to increase groundwater storage managed aquifer recharge (MAR) is essential for the study area. MAR technique, previously known as 'artificial recharge' - a water banking system is a viable adaptation menu for subsequent recovery, future use and environmental benefits (Stefan and Ansems 2018; Sprenger et al. 2017; Dillon 2005; Bouwer 2002). Little works of MAR have been practiced in Bangladesh, mainly focusing to use rooftop rain water for groundwater recharge purpose in most of the cases. IWM (Institute of Water Modeling) and DWASA (Dhaka Water Supply and Sewerage Authority) started to implement a pilot project on MAR using rooftop rain water in 2009 and finally they applied MAR technique at 10 locations of Dhaka city and observed that MAR practices played a vital role to face the challenges of water security, climate change and drainage congestion (IWM 2018). A suitable map for MAR technologies has been prepared and two demonstration plots have been built at Dhaka University campus (Sultana et al. 2009). A preliminary desk study of potential MAR techniques for Dhaka City was conducted and proposed some conceptual designs (Rahman et al. 2013). Department of Geology, University of Rajshahi in collaboration with two Non-Government Organizations (NGOs), DASCOH Foundation and NGOForum, implemented some MAR systems as part of the IWRM initiative at Barind Tract (Rahaman et al. 2019) using rooftop rain water. At the coastal area of Khulna, some MAR 

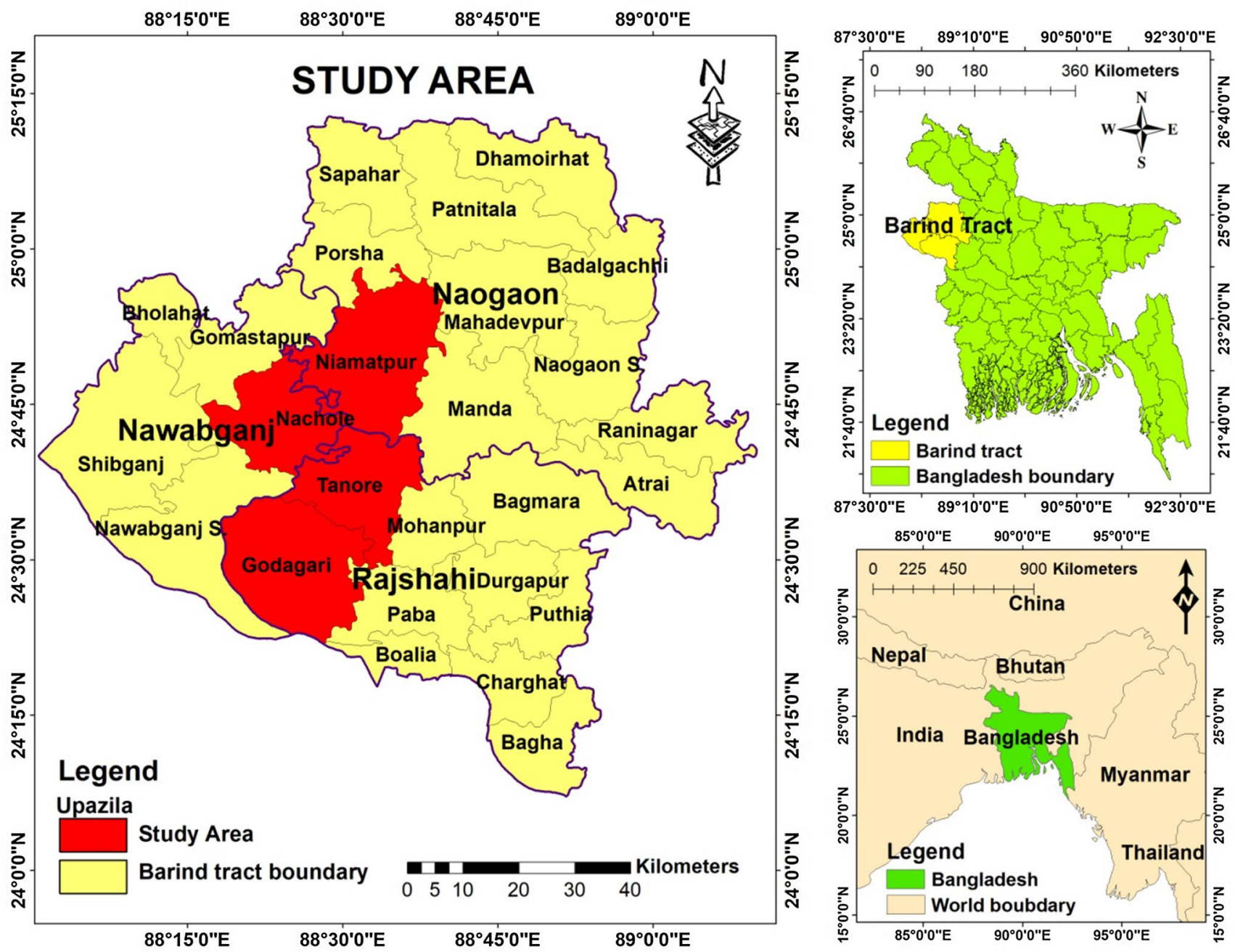

Fig. 1 Location map of the study area

systems have been implemented to provide safe drinking water. In this system, rooftop rain water and pond water are passed through the sand filter and finally recharged groundwater through gravel packed infiltration well and reduced the concentration of salinity of groundwater by dilution with recharged water. People are getting safe drinking water (Sultana et al. 2015; Ahmed et al. 2015).

The BMDA implemented a MAR system using rooftop rain water (Hossain et al. 2019a) and implemented some modified MAR model using run-off storm water (Hossain et al. 2020). The MAR system using rooftop rainwater functions well with poor maintenance, and the MAR systems using run-off water need routine maintenance to avoid clogging and for better functioning. MAR is progressively more practicing globally and reported that $31 \%$ in India and $26 \%$ in USA to meet the extensive agricultural groundwater demand (Dillon et al. 2019). However, there are some constrains for successful installation and sustainable operation of MAR considering hydrogeological, geographic and environmental conditions. Storm water is used for MAR in many countries and it can be one of the main sources of pollutants like suspended solids, dissolve minerals, microorganisms, hydrocarbons and other organic compounds (Chocat et al. 2007). The researchers applied different techniques for pretreatment techniques of storm water for using in MAR. Armentrout et al. (2016) used natural process to treat the storm water by spraying on roof and collecting the water in Pittsburgh Pennsylvania, USA. Vanderzalm et al. (2020) injected the wastewater to the aquifer for the removal of nutrient ( $\mathrm{N}$ and $\mathrm{P}$ ) and successfully removed the nitrogen and total phosphorous to a significant level. Capture of gross solids and sediment is a good practice for the removal of solids from storm water (Erickson and Hernick 2019). Aryal, et al. (2010) discussed various treatment options used for 
storm water and showed that permeable pavement, GPT and swale are used for removal of coarse sediment, litter and suspended solids, while sand filter and bio-retention are used for removal of suspended solids, attached pollutants and some dissolved organics. Retention of storm water in wetland is an effective process to remove turbidity, dissolved pollutants, inorganic and organic matter (Aryal et al. 2010). Azis et al. (2015) constructed a reservoir to reduce the turbidity and eliminate the blockage impact resulting from sedimentation for the recharge well. The constructed wetland or reservoir requires a vast land area for retaining the huge storm water to reduce the turbidity and it might not be effective in the study area because of reduction in total cultivable land. The separate large-scale pretreatment process for storm water in MAR application will increase the construction as well as operational cost. As a consequence, considering the depletion of groundwater level, other situations of Barind tract and experiences of MAR practices in Bangladesh and other part of the world, the present study has been undertaken with an aim at finding out the opportunities and challenges for the implementation of MAR models at the water stressed Barind tract.

\section{Data collection and method}

The information about re-excavated Khal/Kharies (canal), constructed cross dam (check dam) in the re-excavated Kharies, re-excavated ponds, Beels (comparatively large water body) and other water bodies have been collected from the zonal offices of Barind Multipurpose Development Authority (BMDA) to find out the opportunities of MAR technique. Information about office buildings has also been collected for roof top rain water harvesting and groundwater recharge from BMDA. To assess the challenges of MAR techniques, rainfall and groundwater fluctuation data, lithological information have been collected from the BMDA. Information about surface water quality, sedimentation on the canal bed as well as the clogging of top layer of the MAR unit by the silty clay have also been observed. All the data and information are checked for quality and consistency and then processed in the required format.

\section{Results and discussion}

\section{Potential opportunities}

There are many natural and manmade water resources are available in the Barind tract from the early days. These resources can play important role to get rid from water stress in the Barind tract through their proper management with application of appropriate technology. These resources and their potential opportunities are discussed in following sections.

\section{Re-excavated Kharies with cross dam (check dam)}

Derelict Kharies (canals) are generally re-excavated by BMDA to increase their water conserving capacity. To retain the storm water, cross dams are constructed in the re-excavated Kharies at different position maintaining the certain gradient. The re-excavated Kharies are used to

Fig. 2 The re-excavated Sharmaongla Khari with a cross dam under Godagari upzila

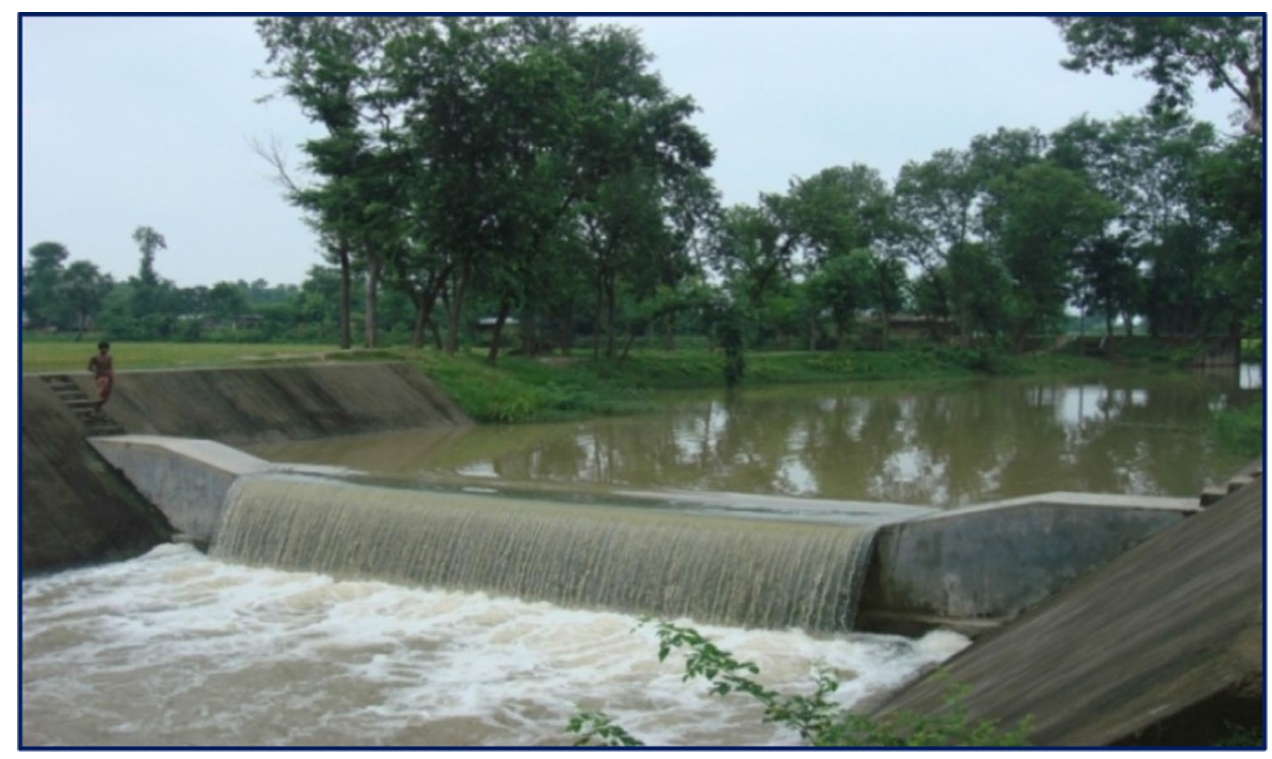


conserve runoff storm water mainly for supplementary irrigation. About $2000 \mathrm{~km}$ re-excavated Khari with 749 cross dam are there in Barind tract in which $514 \mathrm{~km}$ re-excavated Khari and 285 cross dam are available within the study area (BMDA 2018). There is a lot of potential to use this conserved water for ground water recharge by applying proper MAR technique. The modified MAR model performs better for recharging groundwater using conserved storm water in the Khari of Barind tract (Hossain et al. 2020). MAR technique also reverses the declining trend of groundwater level (Hossain et al. 2019b). A re-excavated Khari with cross dam is shown in Fig. 2.

A rubber dam has also been constructed by BMDA at the Barnoi River of Puthia Upazila under Rajshahi district which is shown in Fig. 3. A remarkable portion of conserved water at the upstream of the rubber dam can be used for groundwater recharge purpose.

\section{Re-excavated ponds}

About 1248 nos. of pond have been re-excavated in the study area, while 3098 nos. of re-excavated pond are there in the whole Barind tract (BMDA 2018). These ponds are usually re-excavated with the aim of fish culture and supplementary irrigation. The additional portion of the conserved water in the re-excavated ponds might be possible to use for groundwater recharge with proper MAR structure considering the volume of storage water and requirement of water for fish culture as well as supplementary irrigation. There are two

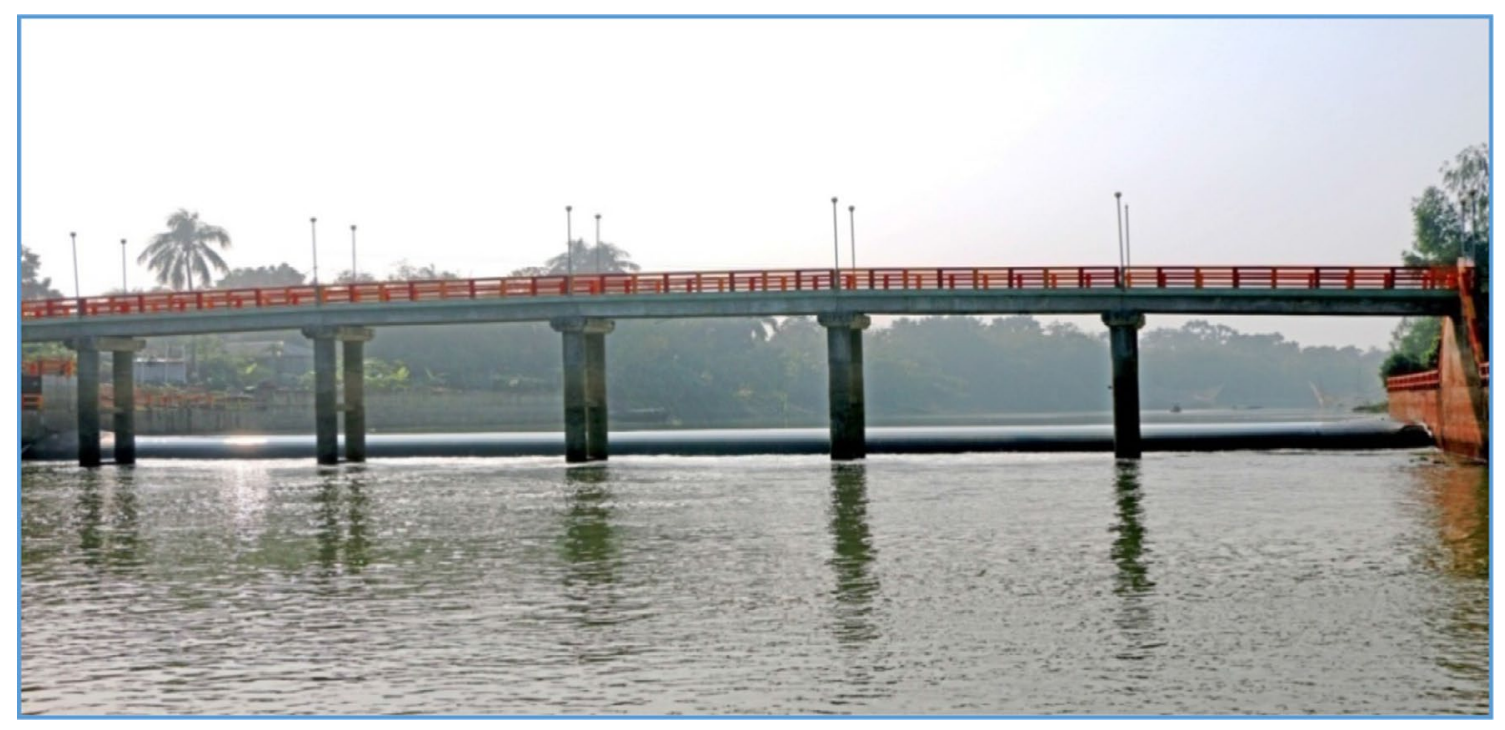

Fig. 3 A Rubber dam across the river Barnai at Jagodishpur, Puthia, Rajshahi

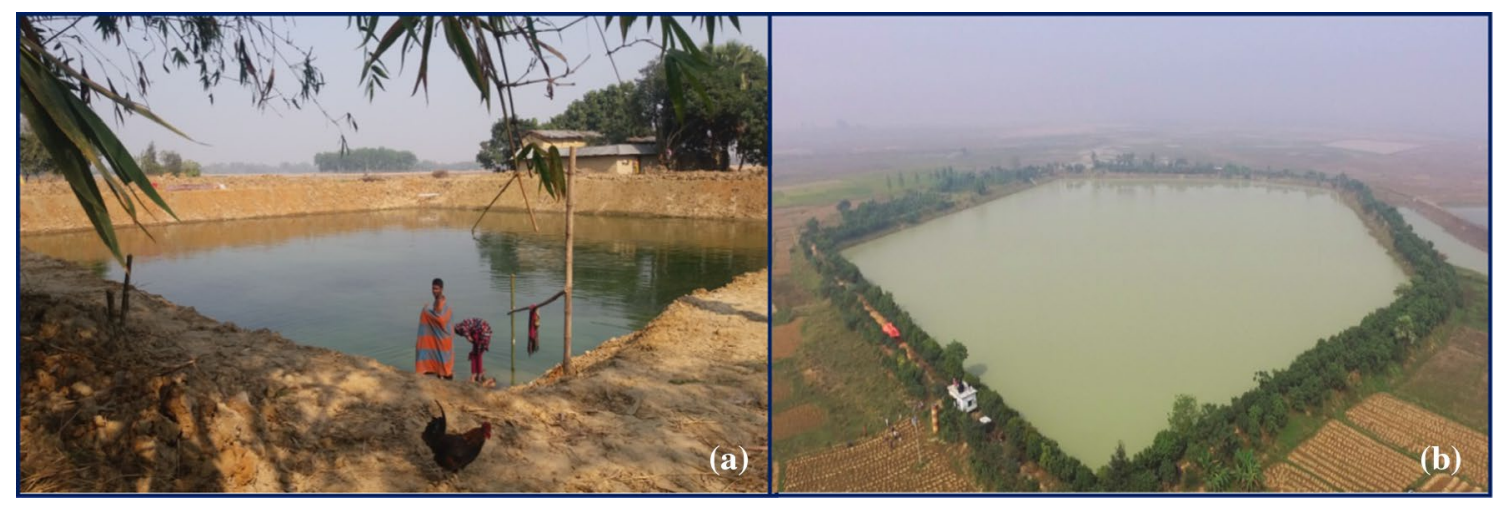

Fig. 4 Re-excavated ponds- a Konnyapara (Re-excavated area 1.09 acre), Niamatpur, b Kushumkunda (Re-excavated area 17 acre), Porsha 
re-excavated ponds are shown in Fig. 4 at Niamatpur Upazila and Porsha Upazila.

The ponds are usually excavated of 4 to $5 \mathrm{~m}$ in depth from ground level depending on the soil condition and the excavated soils are placed around the periphery of the pond to make an embankment. Some inlet pipes of about $450 \mathrm{~mm}$ diameter are horizontally placed at the ground level below an embankment to allow the run-off water to the pond. The water level of the pond reached up to the bottom of the inlet pipe i.e., up to ground level at monsoon. It means that the depth of water of the pond is $4-5 \mathrm{~m}$. Therefore, the storage capacity of Konnypara pond and Kushumkunda dighi (large pond) is about $43,600-54,500 \mathrm{~m}^{3}$ and $680,000-850,000 \mathrm{~m}^{3}$, respectively. The required depth of water for fish culture is varying from 1.5 to $3.5 \mathrm{~m}$ depending on various conditions and species of fish (Basudha et al. 2019). Most of the cases $2 \mathrm{~m}$ depth of water are sufficient for fish culture in case of rain fed pond. Therefore, more than $50 \%$ of storage water is available for recharging the ground water with MAR structure.

\section{Natural Beel}

There are many of Beel (comparatively large water body) in Barind tract of which 5 Beels are within the study area. The names of those Beels in the studya area are Beel Choroi, Durlar Beel (Godagatri Upzila), Beel Kumari (Tanore Upazila), Beel Kasba (Nachole upazila) and Chatra Beel (Niamatpur Upazila). Beels are generally located at the lower elevation where runoff storm water comes from the surroundings catchment area and gets accumulated there. Figure 5 shows a natural Beel (Beel Kumari) at Tanore Upazila.

Fig. 5 Beel Kumari at Tanore upazila under Rajshahi district

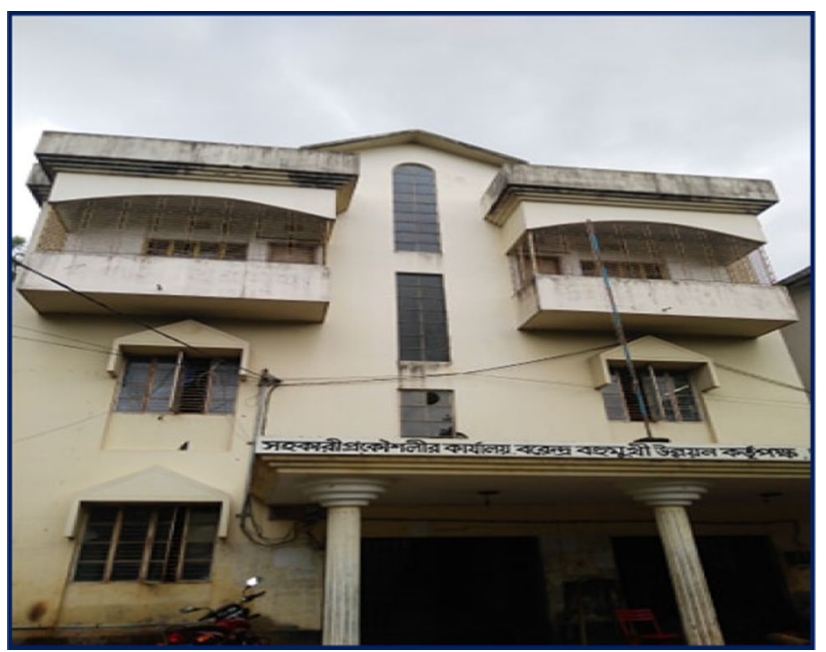

Fig. 6 BMDA Office Building at Tanore upazila under Rajshahi district

The Beels can be re-excavated to conserve more water and use for groundwater recharge using appropriate MAR technology. The modified MAR model performs better to reverse the declining trend of groundwater level in the Beel area of Barind tract (Hossain et al. 2019c).

\section{Roofs of the Office Buildings and Training Shed}

At every Upazila, BMDA and other Departments and organizations have the office buildings and training center. The total catchment areas of these types of buildings are huge, and rain water during the monsoon is also a considerable volume that can be used for groundwater recharge through MAR technique like recharge well (RW) along with proper 
Fig. 7 Dug Well along with overhead tank and solar panel cum rain water receiving structure at Bauchandi, under Niamatpur upazila, Naogaon district

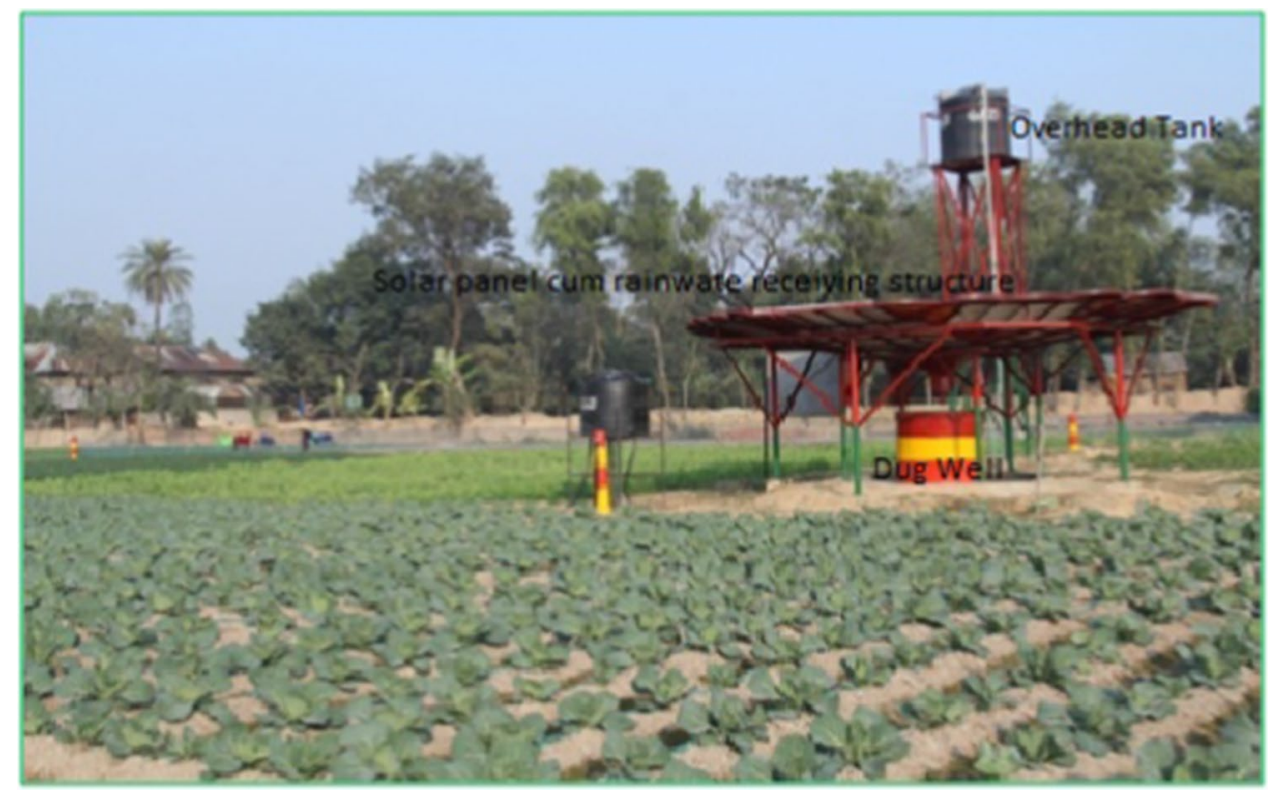

filtration unit. BMDA zonal office of Tanore Upazila is shown in Fig. 6.

Roof area of a similar type of office building at Mohonpur Upazila under Rajshahi district is used as a catchment for harvesting rain water and recharging the ground water with a MAR structure. The augmentation of groundwater level was found after implementation of that MAR unit with the infiltration of rainwater through recharge well (Hossain et al. 2019a).

\section{Dug Well}

About 240 numbers of Dug Well (DW) have been constructed by BMDA with a view to irrigate low water consuming crops like cauliflower, potato, chills and other vegetables. Rainwater receiving structure with solar panel has been constructed over the dug well, and an overhead water tank has also been set on an elevated tower. Rainwater is received by the solar panel cum rain water receiving structure (Fig. 7) during rainfall and stored in the DW. The conserved water is then lifted to the overhead tank by solar energy driven pump and used for irrigation. Moreover, there is a scope to use the surplus water for groundwater recharge in the water stressed Barind tract.

\section{Application of MAR model for storm water management}

In 2013, a recharge well (RW) was constructed by following the conventional MAR technology at the bed of Sharmangla khari (canal) under Godagari Upazila. A filter pit of $3 \mathrm{~m}$ diameter and $3 \mathrm{~m}$ deep was constructed and filled with coarse sand and gravel at its top. Considering the lithology, uPVC blind pipe and strainer with nominal slot width $(1.52 \mathrm{~mm})$ and open area (20\%) were used in RW. The annular space was shrouded by pea gravel. It was observed that the recharge rate decreased to a very low level when the RW with filter pit submerged during the monsoon due to the clogging with thick clay deposition on the top of the filter pit. To avoid such clogging problem and for sustainable operation a water controlling and measuring structure (WCMS) was developed as modified MAR model in 2016. The diameter and the height of the brick made cylindrical hollow shaped WCMS are $3.53 \mathrm{~m}$ and $2 \mathrm{~m}$, respectively. Some water entrance pipes were set horizontally through the wall of the WCMS at different heights from the bottom, starting from $0.6 \mathrm{~m}$ above the khari bed. Double layer water filtering nylon screen was put at the entrance side of the pipe. Caps were used to close and open the pipes at the inner side of the wall. Water is allowed to enter by opening the entrance pipe when the water is observed to be less turbid. Highly turbid water up to $0.6 \mathrm{~m}$ from the canal bed cannot enter into the recharge unit which reduces the clogging problem. Comparatively less turbid water enters through the entrance pipe as they are set $0.6 \mathrm{~m}$ above the canal bed, and the water gets clear when it passes through the water filtering screen set at the entrance pipe. The water becomes further filtered when it moves downward through the sand media of the filter bed and finally it recharges groundwater through the slotted strainer of the RW. In this modified MAR model (Fig. 8) top sand layer can be replaced any time by closing the entrance pipe even if the khari is full with storm water. It is used to recharge groundwater using storm water 
(a)
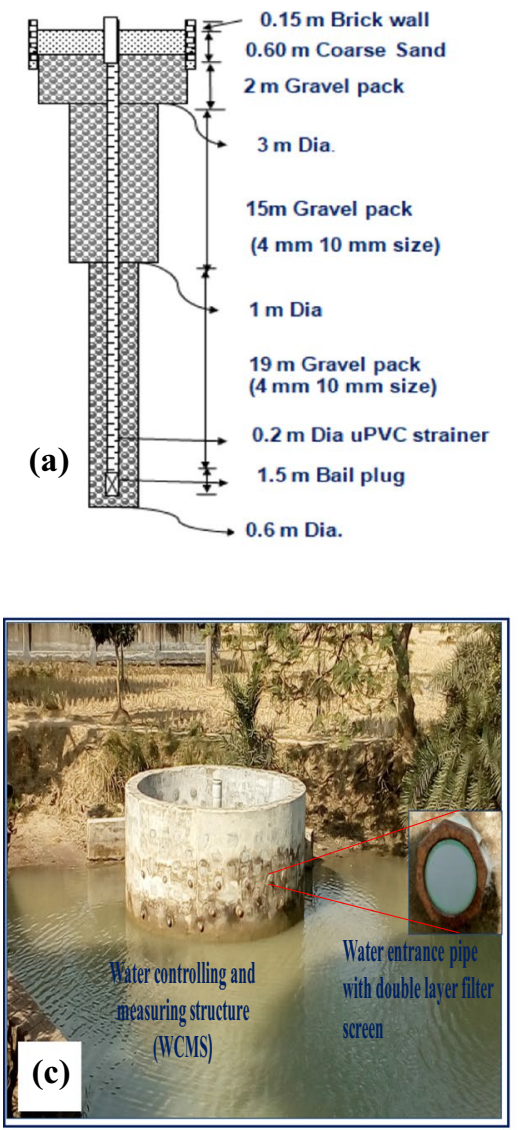
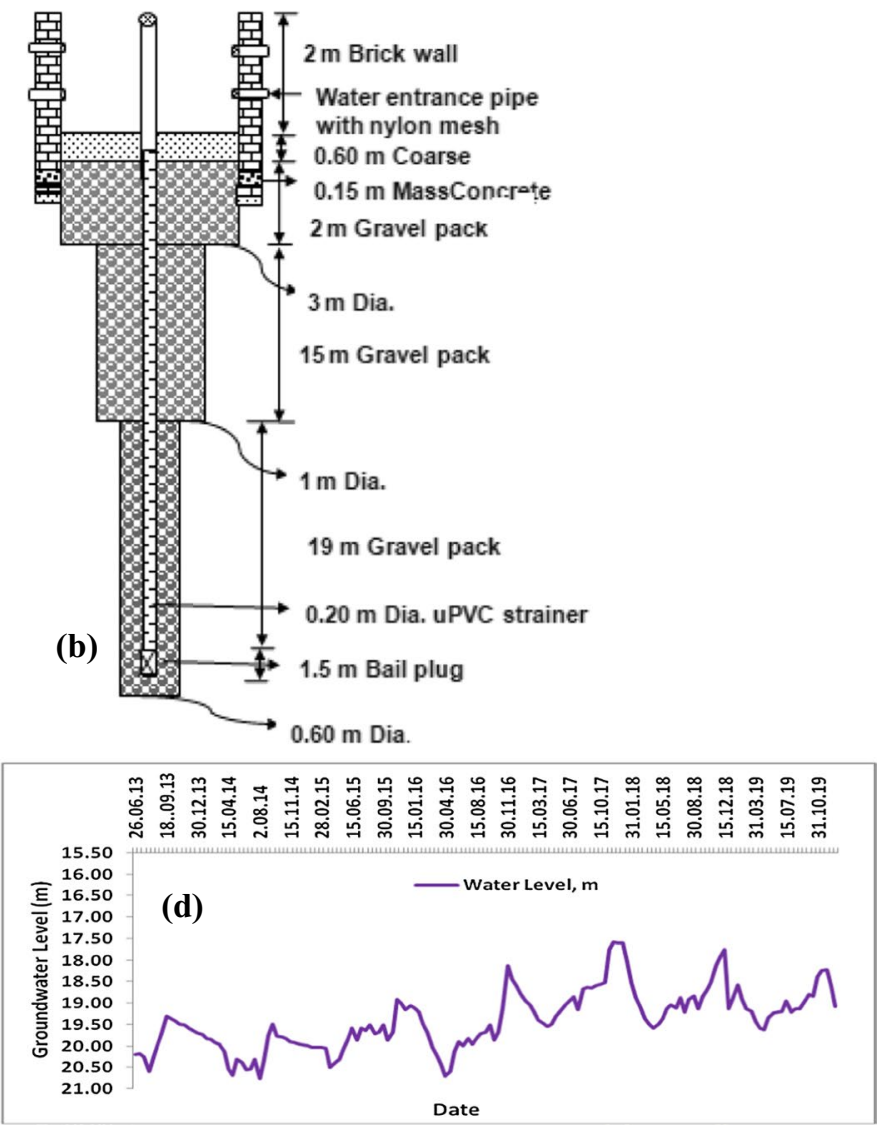

Fig. 8 Sharmangla khari MAR model- a Conventional MAR structure (RW), b Modified and developed MAR structure (RW with WCMS), c Photograph of modified MAR model and $\mathbf{d}$ GWL hydrograph showing recharge performance

accumulated at the canal as run-off. Good performance of recharging groundwater is shown from the hydrograph, and the quality of recharged water remains within the acceptable limit of the standards of drinking water (WHO 2008; BWDS 2005). The MAR model is still performing satisfactorily (Hossain et al 2020) which can be applied for storm water management in the Barind tract. Application of this model is the pioneer attempt in Bangladesh.

\section{Application of MAR model to enhance groundwater recharging using rooftop rainwater}

A recharge well (RW) along with water filtration unit (FU) was designed as the modified MAR model matching with the litholoty as well as the aquifer condition and considering the average maximum daily rainfall and installed at BMDA Mohanpur zonal office campus in 2016 (Fig. 9). Rooftop rain waters are collected from the office building and a training shed by the uPVC pipeline, filtered through the sandgravel filtration media of the FU, and finally recharged to the groundwater through RW. There is an observation well (OW) installed near the RW. A rain gage station and an auto water level recorder (AWLR) record the rainfall information and monitor the groundwater level fluctuation of the observation well at the office campus. The water level is monitored from the BMDA headquarter stationed at Rajshahi by the AWLR through the internet network automatically each day of the year which is the pioneer attempt in Bangladesh (Hossain et al. 2021). It is observed that the hydrograph of groundwater level responds to the rainfall directly and recharging of groundwater is occurred. Quality of recharged water remains within the acceptable limit for drinking use according to standards like Bangladesh Drinking Water Standard (2005) and WHO (2008). This model can be applied for the Barind tract area.

\section{Challenges}

\section{Less rainfall}

Though rainfall is the main source of groundwater recharge but less and uneven distribution of rainfall is one of the 

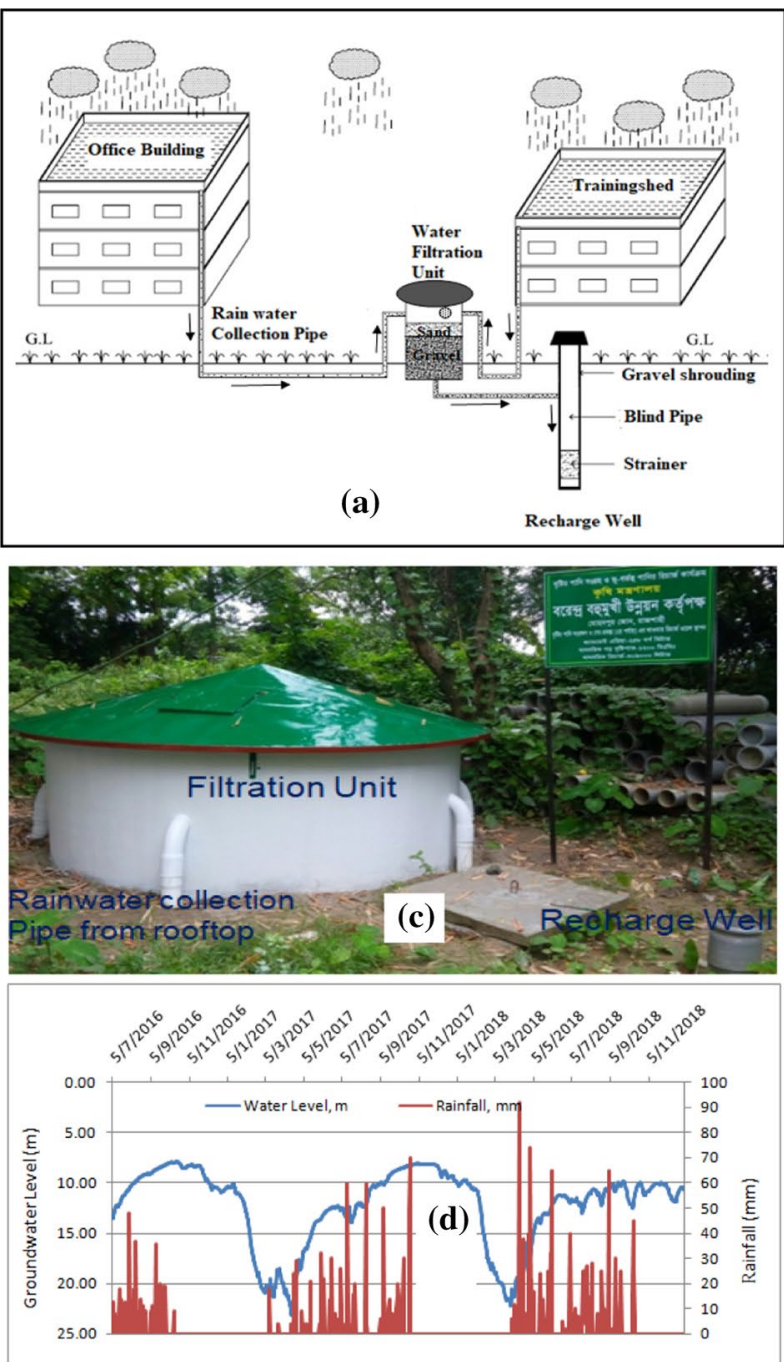

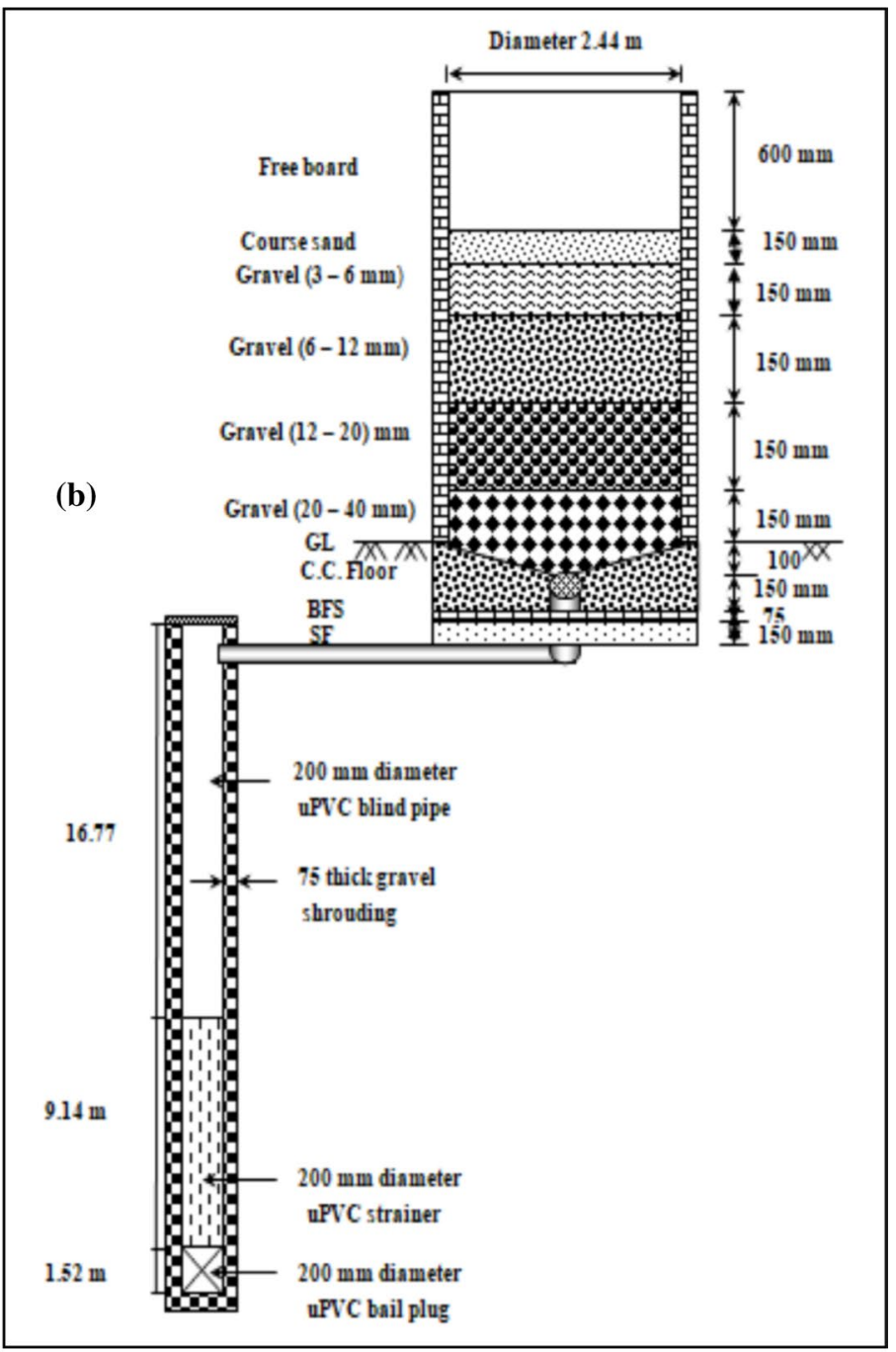

Fig. 9 BMDA Mohanpur office campus MAR model-a Schematic view of complete MAR model, b Longitudinal sectional view of FU and RW, c Photograph of FU with RW and $\mathbf{d}$ GWL hydrograph showing recharge performance with the infiltration of rain water

major challenges of the study area for adoption of MAR techniques. Table 1 shows that the 16 years average rainfall of the study area is $1340.56 \mathrm{~mm}$ which is much lower than the annual average of the country $(2500 \mathrm{~mm})$. The main mechanism of the rainfall in Bangladesh during the summer monsoon season is caused by tropical depressions known as monsoon depression in the Bay of Bengal (Ahmed and Kim 2003). The monsoon depressions enter Bangladesh from the Bay of Bengal with south-to-north trajectory and then turn toward the northwest and west being deflected by the Meghalaya Plateau. As these depressions move farther and farther inland, their moisture content decreases, resulting in decreasing rainfall toward the northwest and west of Bangladesh (Ahmed and Kim 2003).
The yearly rainfall variability is analyzed, and deviations of rainfall from mean values for four Upazilas are shown in Fig. 10. From the analysis, it is found that the deficiency of rainfall from its mean in the year of 2002, 2003, 2005, 2009, 2010, 2012, 1013, 2014, 2016 and 2017 for Godagari Upazila. The rainfall deficiency is varying from 13.22 to $373.22 \mathrm{~mm}$ and average deficiency is of $236.18 \mathrm{~mm}$. Furthermore, if the lowest deficiency of $13.22 \mathrm{~mm}$ in the year of 2010 is neglected the average deficiency is of $260.95 \mathrm{~mm}$. It is remarkable that rainfall deficiency is observed in 10 years out of 16 years. Similarly, deficiency of rainfall is observed for 10 years in Tanor and Nachole upazila, while deficiency in Niamatpur upazila is for nine years. The average rainfall deficiencies of these upazilas are 229.37, 303.60 and 
Table 1 Annual average rainfall of the study area

\begin{tabular}{|c|c|c|c|c|}
\hline \multirow[t]{2}{*}{ Year } & \multicolumn{4}{|c|}{ Rainfall (mm) } \\
\hline & Godagari & Tanore & Niamatpur & Nachole \\
\hline 2002 & 914.00 & 1756.57 & 928.00 & 1932.00 \\
\hline 2003 & 869.00 & 1400.00 & 1014.00 & 1591.75 \\
\hline 2004 & 2451.90 & 1632.00 & 904.25 & 1187.00 \\
\hline 2005 & 1110.40 & 1607.00 & 1259.00 & 1141.00 \\
\hline 2006 & 1290.12 & 1889.01 & 1087.81 & 1616.00 \\
\hline 2007 & 1390.44 & 1790.00 & 1591.00 & 2029.00 \\
\hline 2008 & 1401.10 & 2241.00 & 2295.00 & 1195.10 \\
\hline 2009 & 932.00 & 1048.00 & 1310.00 & 1228.00 \\
\hline 2010 & 1208.00 & 917.50 & 1262.00 & 987.00 \\
\hline 2011 & 1440.00 & 1311.50 & 1537.00 & 1496.00 \\
\hline 2012 & 904.00 & 1106.50 & 906.00 & 742.00 \\
\hline 2013 & 885.00 & 1087.00 & 886.00 & 943.00 \\
\hline 2014 & 848.00 & 1321.50 & 1631.00 & 1224.00 \\
\hline 2015 & 1715.50 & 1405.00 & 1565.00 & 1740.00 \\
\hline 2016 & 1025.00 & 1231.00 & 1884.00 & 1065.00 \\
\hline 2017 & 1155.00 & 1248.00 & 1756.00 & 1332.00 \\
\hline Total rainfall (mm) & 19539.46 & 22991.58 & 21816.06 & 21448.85 \\
\hline $\begin{array}{l}\text { Upazila avg. rainfall } \\
\text { (mm) }\end{array}$ & 1221.22 & 1436.97 & 1363.50 & 1340.55 \\
\hline $\begin{array}{l}\text { Study area avg. rainfall } \\
(\mathrm{mm})\end{array}$ & 1340.56 & & & \\
\hline
\end{tabular}

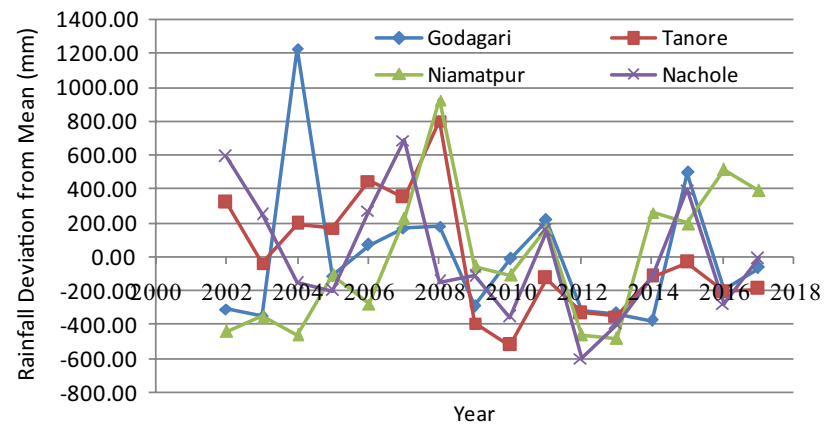

Fig. 10 Rainfall deficiencies from mean values and poor rainfall years in the study area

$214.67 \mathrm{~mm}$, respectively. Another observation is important that rainfall deficiencies are observed in Godagari, Tanore and Nachole upazilas after 2008, while in Niamatpur upazila is 2002 to 2006 and again 2009 to 2013. Therefore, rainfall deficiency is observed in the recent past years in general.

The challenge of less rainfall in the study area is needed to be overcome. Appropriate technology should be developed considering the local conditions and available quantity of rainwater for proper collection with the minimization of losses for the implementation of suitable MAR technique that would be a boon for the study area.

\section{Thick top clay layer}

Thick top clay layer (Barind clay of Pleistocene age) is one of the major challenges of Barind tract. More than $15 \mathrm{~m}$ thick top clay prevails in almost all the study area (Fig. 11). The bore log lithology shows that 19.81-30.48 m thick clay layer remains from the ground surface to the aquifer which resists the percolation of water as well as natural recharge of groundwater. So, surface systems of MAR technique is not suitable; modified RW system will be adopted for recharging of groundwater in the study area.

Barind Tract in north-west Bangladesh geomorphologically formed with Pleistocene red soil. Aftabuzzaman et al. (2013) carried out detailed investigation on the formation of Barind tract and found that Barind tract consisted of kaolinite, illite and chrysotile with significant amount of opal-CT. The soil sample collected from Nachole and examined by X-ray diffractions showed the composition of kaolinite, illite, quartz and opal-CT while in places it was found chrysotile instead of kaolinite. Clay mineral compositions of different soil horizons indicated two different types of clay assemblages, viz. (a) illitekaolinite and (b) illite-chrysotile. The clay mineral assemblage indicates that soil horizons were formed under low temperatures with alkaline and reducing conditions. However, other soil horizons of illite-kaolinite clay mineral assemblage indicate that soils were possibly formed under humid, temperate and well drained conditions. These two soil horizons were formed under different geochemical, geomorphological and climatic conditions from different parent materials (Aftabuzzaman et al. 2013). This opal-CT along with the general lack of fossils and presence of glass shards was indicative of a volcanogenic rather than biogenic origin for the Opal-CT in the Barind tract.

Geomorphologically, the area is subdivided into three geological units as: (1) Barind clay residuum-overlies and developed on Pleistocene alluvium; (2) Holocene Ganges flood-plain alluvium; (3) Active channel deposits of the Ganges and major distributaries (modern alluvium). The hydraulic conductivity of the aquifer varies from 18 to $29 \mathrm{~m} /$ day for Godagari, 39-56 m/ day for Tanore, 12-35 m/day for Niamatpur and 12-17 m/day for Nachole Upazila (IWM 2012). IWM calculated potential recharge using mathematical modeling tool and found 521, 357, 451 and $496 \mathrm{~mm}$ for Godagari, Tanore, Niamatpur and Nachole Upazila, respectively (IWM 2012). Kanoua and Merkel (2015) calculate the groundwater recharge in Titas upazila under Comilla district using water balance method and found three different values (984, 459 and $396 \mathrm{~mm} / \mathrm{a}$ ), while $230 \mathrm{~mm} / \mathrm{a}$ was found by water table fluctuation method. 


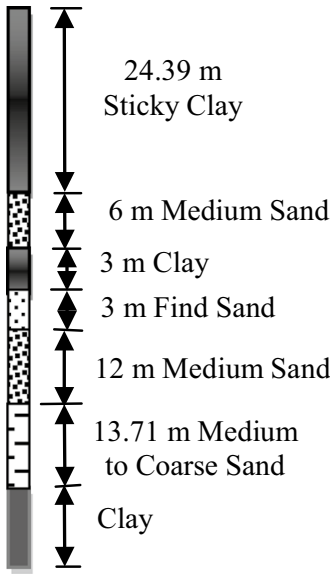

(a)

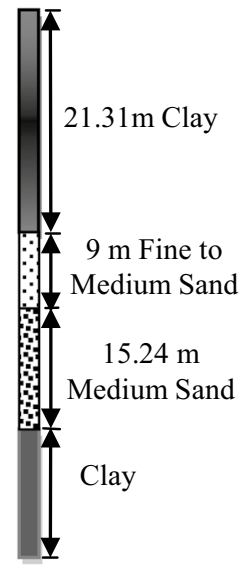

(b)

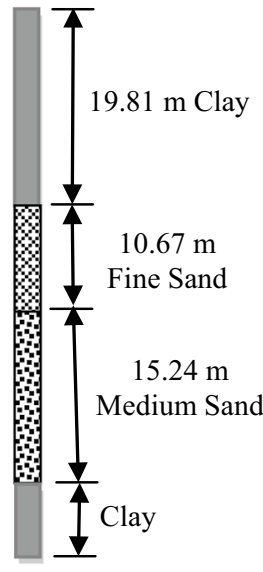

(c)

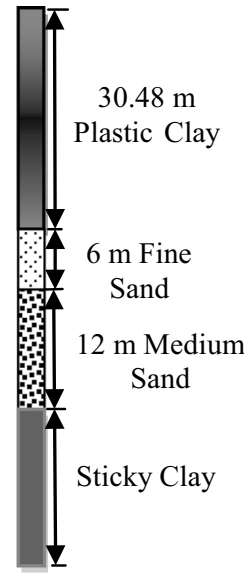

(d)

Fig. 11 Bore log lithology- a Mouza-Muradpur-2, J.L. No- 148, Plot No.-437 Upazila- Nachole, District- Chapai Nawabgonj; b Mouza- Nimdighi, J.L. No.- 151, Plot No.-768,Upazila- Niamatpur,

\section{Depletion of groundwater level (GWL)}

Groundwater level (GWL) of the study area is getting depleted day by day. So it is another challenge for the study area. The groundwater situation of Tanore upazila, Niamatpur upazila, Godagari upazila and Nachole upazila under the study area is plotted and presented in Fig. 12. Gradual declination of GWL is observed in all the upazilas of the study area (Fig. 12).

Continuous depletion of GWL indicates over stress on groundwater in the study area. To reverse the declining trend of GWL, appropriate MAR technique needs to be applied.

\section{Highly turbid runoff storm water}

The runoff storm water of the canal is highly turbid. The major cause of this high turbidity is due the presence of silt, clayey silt, clay and other organic matter in suspending condition (Page et al. 2018). Water samples collected from Sharmangla canal at Godagari upazila and Rasulpur canal at Niamatpur upazila are tested for turbidity in the laboratory of BMDA. Water does not available round the year in the canals. Therefore, samples were collected usually at the rainy period. The turbidity was measured once in a year from 2014 to 2018 within the month of April to July for Sharmangla canal. The turbidity of Sharmangla canal water varies from 30 to 79 NTU. Again, Rasulpur canal water was tested from 2013 to 2018 within the month of June to September and the turbidity varies from 20 to 80 NTU. Usually the months of May to September are rainy period when water is available for groundwater recharge. However, the turbidities of both canals water are extremely higher than the allowable

District-Naogaon; c Mouza-Aira- 2, J.L. No- 67, Plot No.-261 Upazila- Tanore, District- Rajshahi; d Bore log for Mouza- Amtoli, J.L. No- 195, Plot No.-113, Upazila- Godagari, District- Rajshahi

limit (10 NTU for drinking). The results (Table 2) depicted that the water contains high concentration of suspended matter usually silt, clayey silt, clay and other organic matter that may cause the clogging of recharge unit.

Basically there is no guideline for maintaining the turbidity level for ground water recharge. Sultana et al. (2015) maintained the turbidity at 5 NTU for recharge by using sand filter and weekly to monthly maintenance was performed for sustainable operation. Sultana et al. (2015) also mentioned that RW is in high risk when turbidity is greater than 10 NTU and low risk is at less than 3 NTU. Hence turbid water is the main cause of clogging the recharge unit. For sustainable recharge of groundwater, suitable filtration unit needs to be developed with RW.

\section{Sedimentation on the canal bed and clogging of RW}

A simple conventional recharge well was constructed up to the depth of permeable strata at the canal bed. The well was lined with $250 \mathrm{~mm}$ brick masonry wall and filled with gravel and fine sand at the top one meter (Fig. 13). The canal is filled with rainwater during the monsoon and dried up at the summer season. It was thought that the canal water would percolate through the gravel and sand packed RW when it would be submerged during the rainy season. There are two observation wells were also installed to measure the groundwater level as required. Immediately after submergence the recharge performance was well but it was getting gradually slower and finally stopped after few days. It is mainly due to the sedimentation of silt and clay materials from the turbid water on the top of the recharge well (Hossain et al. 2019b). 


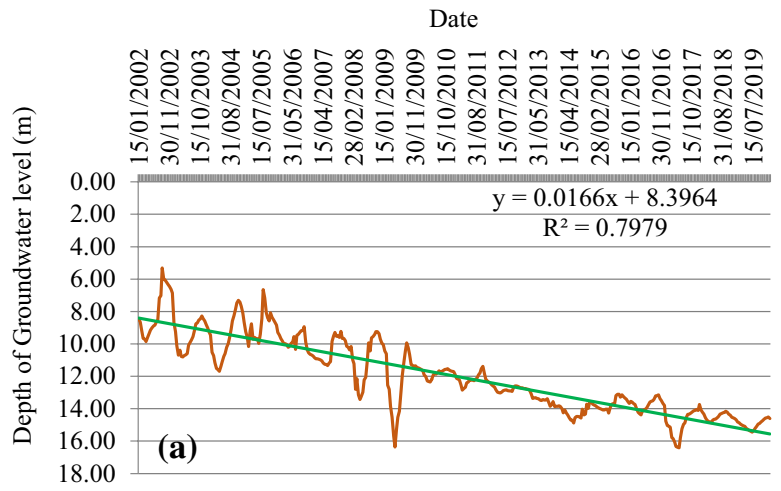

Date

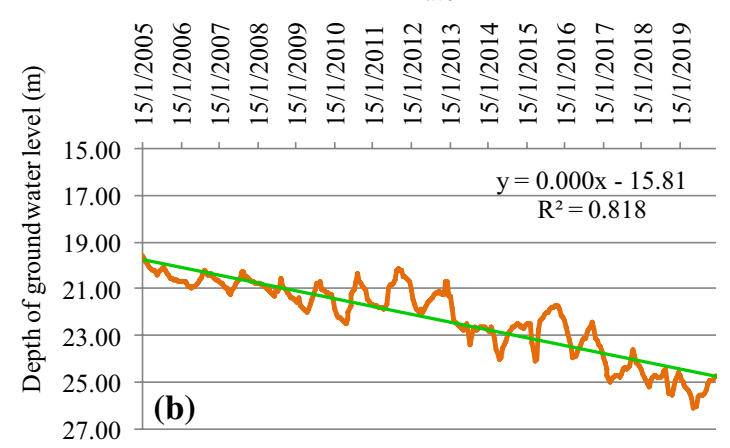

Date
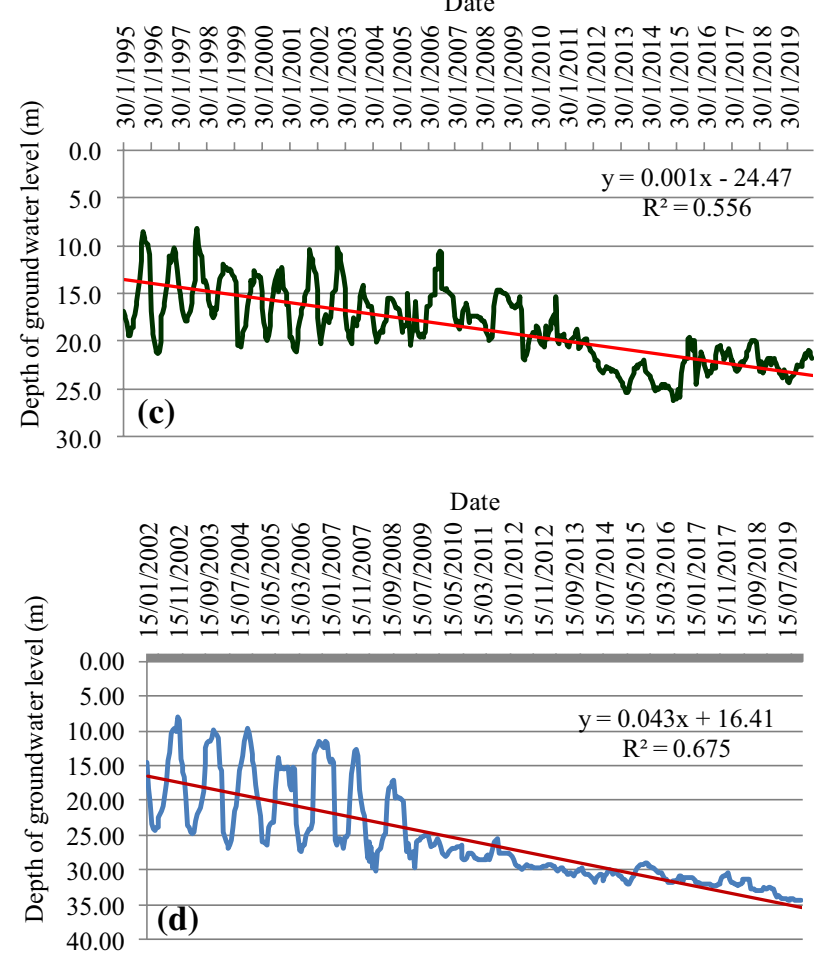

Fig. 12 a GWL Hydrograph at Haripur, Tanore upazila b GWL Hydrograph at Darajpur, Niamatpur upazila c GWL Hydrograph at Amtoli-1, Godagari upazila d GWL Hydrograph at Ratipur, Nachole upazila
Figure 13 shows the clogging of conventional recharge technique and sedimentation of canal bed.

The thickness of the deposited sediment composed of silt, clayey silt and clay on the top of the recharge well and canal bed was measured when the canal was completely dried up to be of 40-80 mm (Hossain et al. 2019b). So, to overcome this challenge modified MAR technique along with filtration unit is needed for continuous and sustainable function.

\section{Low flow of water in rivers}

Low water flow in rivers is another challenge of the study area. It is well known that water is flowing toward the lower potential level from the higher potential level. The movement of water from river to aquifer and from aquifer to river is natural depending on the difference of water level of river and aquifer. During the dry season water level in the rivers of the study area goes down which causes very low or no flow condition. Due to the lower water level in the river around the Barind tract than GWL of the nearby aquifer causes movement of groundwater from the aquifer to the river making declination of GWL with steep sloppy toward the river. Average yearly water loss from Barind tract across the Ganges is $13.45 \mathrm{Mm}^{3} /$ year and across the Indian border is $7.24 \mathrm{Mm}^{3} /$ year (IWM 2006). Therefore, without maintaining the sufficient depth of water flow in the river the initiative of storage of water in aquifer with proper MAR application will not be successful.

\section{Lack of practical knowledge}

To get a satisfactory result on any experiment or study, it is necessary to have both theoretical and practical knowledge. Though MAR is not a new technology in the world but very few works have been performed in Bangladesh limiting to use of rooftop rain water only. Besides, lack of knowledgeable and experienced persons on this issue is also a problem. So to make the MAR technique a success, especially in case of using runoff storm water as well as surface water, collective effort of experts, experiments in both in fields and laboratories are needed. Special training and practical visit of such type of works performed in other countries are essential.

\section{Conclusions}

Desert like drought prone Barind tract with less rainfall and 18-30 m thick top clay layer demands MAR techniques to recover the groundwater level as well as to restore 
Table 2 Turbidity value for the tested sample of surface water (Khari water)

\begin{tabular}{llll}
\hline Name of Khari (canal) & Date of testing & $\begin{array}{l}\text { Turbidity } \\
\text { (NTU) }\end{array}$ & Comments \\
\hline Sharmangla, Godagari & 02.04 .14 & 40 & The allowable limit of turbidity of drinking water is 10 NTU (ECR 1997). To reduce the \\
& 15.07 .15 & 79 & clogging risk turbidity should be maintained within 3-5 NTU (Sultana et al. 2015) \\
13.07 .16 & 57 & \\
& 17.05 .17 & 30 \\
& 25.06 .18 & 80 \\
Rasulpur, Niamatpur & 15.07 .13 & 68 \\
& 30.06 .14 & 48 \\
& 15.07 .16 & 30 \\
& 20.07 .17 & 20 \\
& 25.06 .18 & 20 \\
03.09 .18 & 80 \\
\hline
\end{tabular}

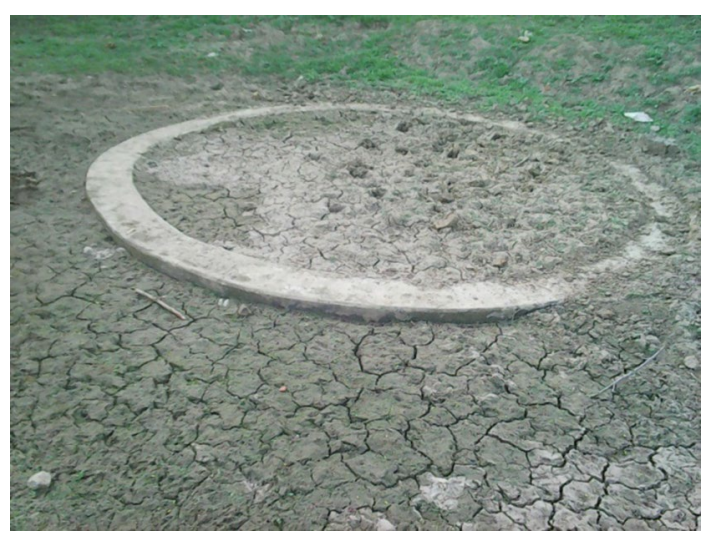

Fig. 13 Clogged RW along with silted Canal bed at Godagari

groundwater as a water bank for the use in crucial period. Though there are significant number of opportunities like re-excavated canal with cross dam and rubber dam, ponds, beels (comparatively large water body) and roofs of office building to harvest rain water and groundwater recharge but lots of challenges like less rainfall, thick top clay materials, depletion of GWL, water turbidity and clogging are also the barriers to implement the MAR technique successfully. Also proper depth of water in the surrounding rivers including Ganges, Mahananda, Atrai needs to be maintained for effective application of MAR technologies. Practical knowledge and collective efforts and pilot study program are also needed for reviving the Barind tract making groundwater available with proper designed and modified MAR techniques.
Acknowledgements The authors wish to thank the Barind Multipurpose Development Authority (BMDA) for providing different data and cooperation.

Funding This research was conducted with self-funding.

\section{Declarations}

Conflict of interest The authors declare no conflicts of interest regarding the publication of this paper.

Open Access This article is licensed under a Creative Commons Attribution 4.0 International License, which permits use, sharing, adaptation, distribution and reproduction in any medium or format, as long as you give appropriate credit to the original author(s) and the source, provide a link to the Creative Commons licence, and indicate if changes were made. The images or other third party material in this article are included in the article's Creative Commons licence, unless indicated otherwise in a credit line to the material. If material is not included in the article's Creative Commons licence and your intended use is not permitted by statutory regulation or exceeds the permitted use, you will need to obtain permission directly from the copyright holder. To view a copy of this licence, visit http://creativecommons.org/licenses/by/4.0/.

\section{References}

Aftabuzzaman M, Kabir S, Islam MK, Alam MS (2013) Clay mineralogy of the Pleistocene soil horizon in Barind tract, Bangladesh. J Geol Soc India 81:677-684

Ahmed KM (2006) Barind Tract. Banglapedia, National Encyclopedia of Bangladesh. Retrieved from: http://www.banglapedia.org/httpd ocs/HT/G_0209.HTM

Ahmed R, Kim IK (2003) Patterns of daily rainfall in Bangladesh during the summer monsoon season: case studies at three stations. Phys Geogr 24(4):295-318. https://doi.org/10.2747/0272-3646. 24.4.295 
Ahmed KM, Sultana S, Groen K, Tuinhof A, Islam R (2015) Development of optimal design of aquifer storage and recovery for providing safe water to vulnerable communities of coastal Bangladesh. In proceedings of International conference on Climate Change in relation to Water and Environment (I3CWE-2015), DUET, Gazipur, Bangladesh: 471-478, 2015

Ahmeduzzaman M, Kar S, Asad A (2012) A study on ground water fluctuation at BarindArea Rajshahi. Eng Res Appl (IJERA) 2(6): 1465-1470

Armentrout T, Barbeau N, Kincaid J, Phillips N, Pittore E, Hunsucker III JF, Smith JE (2016) Natural treatment of stormwater runoff. IJRDO-Journal Of Biological Science. Volume-2 (8), Paper-1.

Aryal R, Vigneswaran S, Kandasamy J, Naidu R (2010) Urban stormwater quality and treatment. Korean J Chem Eng 27(5):13431359. https://doi.org/10.1007/s11814-010-0387-0

Azis A, Yusufa H, Faisala Z, Suradi M (2015) Water turbidity impact on discharge decrease of groundwater recharge in recharge reservoir. Procedia Eng 125(2015):199-206

Baker BH, Omer A, Aldridge CA (2013) Water availability and use water resources of North America. Springer, Berlin, Heidelberg, pp 163-174

Balasubramanian A (2015) The World's Water, Technical Report, Centre for Advanced Studies in Earth Science, University of Mysore, Mysore. Retrieved from https://www.researchgate.net/publication/ 315123891_The_World's_Water/references

Basudha Ch, Singh RK, Sureshchandra N, Soranganba N, Sobita N, Singh TB, Singh LK, Singh IM, Prakash N (2019) Fish farm design and pond construction for small scale fish farming in Manipur. Technical Bulletin No. RCM(TB)- 12. ICAR Research Complex for NEH Region, Manipur Centre, Lamphelpat, Imphal, 27page

BDWS (Bangladesh Drinking Water Standards) (2005) Bangladesh Water Quality Standard (Dhaka, Bangladesh).

BMDA (2018) Development Activities. Monthly Report FY 20172018. Barind Multipurpose Development Authority (BMDA), Rajshahi, Bangladesh

Bouwer H (2002) Artificial recharge of groundwater: hydrogeology and engineering. Hydrogeol J. https://doi.org/10.1007/ s10040-001-0182-4

Chocat B, Ashley R, Marsalek J, Matos RS, Rauch W, Schilling W, Urbonas B (2007) Toward the sustainable management of urban stormwater. Indoor Built Environ 16(3):273-285

Dillon P (2005) Future management of aquifer recharge. Hydrogeol J 13:313-316

Dillon P, Stuyfzand P, Grischek T, Lluria M, Pyne RDG, Jain RC, Bear J, Schwarz J, Wang W, Fernandez E, Stefan C, Pettenati M, van der Gun J, Sprenger C, Massmann G, Scanlon BR, Xanke J, Jokela P, Zheng Y, Rossetto R, Shamrukh M, Pavelic P, Murray E, Ross A, Valverde JPB, Nava AP, Ansems N, Posavec K, Ha K, Martin R, Sapiano M (2019) Sixty years of global progress in managed aquifer recharge. Hydrogeol J 27:1-30

Erickson AJ, Hernick MA (2019) Capture of Gross Solids and Sediment by Pretreatment Practices for Bioretention, Final Report for the Project: field performance assessment of sediment and gross solids removal from surface inlet pretreatment practices for bioretention. St. Anthony Falls Laboratory, University of Minnesota, 2 Third Avenue SE Minneapolis, MN 55455

Genda H (2016) Origin of Earth's oceans: an assessment of the total amount, history and supply of water. Geochem J 50:27-42. https://doi.org/10.2343/geochemj.2.0398

Hossain MI, Bari N, Miah SU (2019b) Operational constraints in conventional managed aquifer recharge in Barind area at NorthWestern Region of Bangladesh. Procedings of 2nd International
Conference on Planning, Architechture \& Civil Engineering, Faculty of Civil Engineering, Rajshahi University of Engineering \& Technology, Rajshahi, 07-09 February, 2019

Hossain MI, Bari N, Miah SU, Rahman MF (2019) Application of modified MAR Model in Barnai river Basin, NW Bangladesh: a performance study. Hydrology. https://doi.org/10.11648/j.hyd. 20190702.11

Hossain MI, Bari N, Miah SU, Jahan CS, Rahman MF (2019b) MAR technique to reverse the declining trend of groundwater level in Barind area, NW, Bangladesh. J Water Resour Prot 11:748-757. https://doi.org/10.4236/jwarp.2019.116045

Hossain MI, Bari N, Miah SU, Jahan CS, Rahman MF (2020) Performance of MAR model for storm water management in Barind Tract, Bangladesh. Groundw Sustain Dev. https://doi.org/10. 1016/j.gsd.2019.100285

Hossain MI, Bari N, Miah SU, Kafi AAI, Nasher NMR (2021) Application of modified managed aquifer recharge model for groundwater management in drought-prone water- stressed Barind Tract, Bangladesh. Environ Chall. https://doi.org/10.1016/j.envc.2021.100173

Imon AHMR, Ahmed M (2013) Water level trend in Barind area. Malays J Math Sci 7(1):1-15

IWM (2006) Ground water model study for deep tubewell installation project in Barind Area, Volume I, Main Report, Institute of Water Modelling.

IWM (2012) Groundwater resources study and decision support system development of Rajshahi, Naogaon, Chapai Nawabganj, Pabna and Natore Districts and Also Remaining District of Rajshahi Division through Mathematical Model Study for Barind Integrated Area Development Project, Phase-III, Final Report, Vol. 1, Institute of Water Modelling.

IWM (2018) Study on artificial recharge to aquifer by rainwater harvesting from building roof -tops in Dhaka City. Draft Final Report submitted to Dhaka Water supply and Sewerage Authority

Jahan CS, Rahman ATMS, Mazumder QH, Kamruzzaman M (2015) Adaptation for climate change effect on groundwater resource through MAR technique in drought Prone Barind Area, Rural Bangladesh. In S.M. Ali (Ed.), Bangladesh: Combating Land Degradation and Drought. Dhaka: Series-II, Department of Environment (DoE), Ministry of Environment (MoE), GoB, 61-83, ISBN 978-984-33-9991-5

Jahan CS, Mazumder QH, Adham MI, Hossain MMA, Haque AM (2010) Study on groundwater recharge potentiality of Barind Tract, Rajshahi District, Bangladesh Using GIS and remote sensing technique. J Geol Soc India 75:432-438

Jahan CS, Islam MA, Mazumder QH, Asaduzzaman M, Islam MM, Islam MO, Sultana A (2007) Evaluation of depositional environment and aquifer condition in the Barind Area, Bangladesh, using gamma ray well log data. J Geol Soc India 70:1070-1107

Kanoua W, Merkel B (2015) Groundwater recharge in Titas Upazila in Bangladesh. Arab J Geosci 8(3):1361-1371

Mekonnen, Mesfin M, Hoekstra, Arjen Y (2016) Four billion people facing severe water scarcity. Science Advances. 2 (2): e1500323. Bibcode:2016SciA.2E0323M. doi:https://doi.org/10.1126/sciadv. 1500323. ISSN 2375-2548. PMC 4758739. PMID 26933676.

Mojid MA, Parvez MF, Mainuddin M, Hodgson G (2019) Water table trend-a sustainability status of groundwater development in North-West Bangladesh. Water 11(6):1182. https://doi.org/10. 3390/w11061182

Page D, Bekele E, Vanderzalm J, Sidhu J (2018) Managed Aquifer Recharge (MAR) in sustainable urban water management. Water 10:239. https://doi.org/10.3390/w10030239

Rahman M, Mahbub AQM (2012) Groundwater depletion with expansion of irrigation in Barind Tract: a case study of Tanore Upazila. 
J Water Resour Prot 4:567-575. https://doi.org/10.4236/jwarp. 2012.48066

Rahman MF, Jahan CS, Mazumder QH (2019) Rainwater harvesting: practiced potential for Integrated water resource management in drought-prone Barind Tract, Bangladesh. Groundw Sustain Dev. https://doi.org/10.1016/j.gsd.2019.100267

Rahman MA, Wiegand BA, Badruzzaman ABM, Ptak T (2013) Hydrogeological analysis of the upper Dupi Tila Aquifer, towards the implementation of a managed aquifer-recharge project in Dhaka City, Bangladesh. Hydrogeol J. https://doi.org/10.1007/ s10040-013-0978-z

Rahman ATMS, Jahan CS, Mazumder QH, Kamruzzaman M, Hosono $\mathrm{T}$ (2017) Drought analysis and its implication in sustainable water resource management in Barind Area, Bangladesh. J Geol Soc India 89:47-56

Rahman ATMS, Kamruzzaman M, Jahan CS, Mazumder QH, Hossain A (2016a) Evaluation of spatio-temporal dynamics of water table in NW Bangladesh-an integrated approach of GIS and statistics. Sustain Water Resour Manag 2:297-312

Rahman ATMS, Kamruzzaman M, Jahan CS, Mazumder QH, Hossain A (2016b) Long-term trend analysis of water table using MAKESENS model and sustainability of groundwater resources in drought prone Barind area, NW Bangladesh. J Geol Soc India 87:179-193

Rasheed KBS (2008) Bangladesh: resource and environmental profile. A H Development Publishing House, Dhaka

Sprenger C, Hartog N, Hernández M, Vilanova M, Grützmacher G, Scheibler F, Hannappel S (2017) Inventory of managed aquifer recharge sites in Europe: historical development, current situation and perspectives. Hydrogeol J 25:1909-1922. https://doi.org/10. 1007/s10040-017-1554-8

Stefan C, Ansems N (2018) Web-based global inventory of managed aquifer recharge applications, sustainable. Water Resour Manag 4:153-162. https://doi.org/10.1007/s40899-017-0212-6
Sultana S, Ahmed KM, Mia MB (2009) Prospects of Artificial Recharge for Augmentation of the Upper Dupi Tila Aquifer in Dhaka City, Bangladesh. In ISMAR 7. Proceedings of the symposium Achieving Ground Water Supply Sustainability \& Reliability through Managed Aquifer Recharge, Abu Dhabi, UAE : 35-41

Sultana S, Ahmed KM, Mahtab-ul-Alam SM, Hasan MM, Tuinhof A, Ghosh S, Rahman MS, Ravenscroft P, Zheng Y (2015) Low-cost aquifer storage and recovery: implications for improving drinking water access for rural communities in coastal Bangladesh. J Hydrol Eng. https://doi.org/10.1061/(ASCE)HE.1943-5584. 0001100

Vanderzalm J, Page D, Regel R, Ingleton G, Nwayo C, Gonzalez D (2020) Nutrient transformation and removal from treated wastewater recycled via Aquifer Storage and Recovery (ASR) in a carbonate aquifer. Water Air Soil Pollut 231:65. https://doi.org/10. 1007/s11270-020-4429-

WEF (2019) The Global Risks Report 2019 14th Edition. The World Economic Forum in partnership with Marsh \& McLennan Companies and Zurich Insurance Group. http://www3.weforum.org/ docs/WEF_Global_Risks_Report_2019.pdf

WHO (World Health Organization) (2008) Guidelines for drinkingwater quality, 3rd edn. World Health Organization, Geneva

Publisher's Note Springer Nature remains neutral with regard to jurisdictional claims in published maps and institutional affiliations. 